Magdalena Siwiec

Uniwersytet Jagielloński

\title{
Znaki na czarnym płótnie, czyli o estetyce przemijającego piękna i o twórczej melancholii Charles'a Baudelaire'a*
}

\section{Abstract \\ Signs on Black Canvas, or Charles Baudelaire's Aesthetics of Transient Beauty and Creative Melancholy}

This article focuses on Charles Baudelaire's poetics of negativity which exploits absence, blackness, negation, defectiveness, associated by the poet in a paradigmatic way with melancholy and the aesthetics of transient beauty. The basis of the proposed interpretation is the paradoxical metaphor of luminous blackness (a black sun, a radiance without source, a black star, a black canvas), which the poet exploits in his metatextual works. The paper focuses on poems in which Baudelaire approaches that which is beyond the limits of expressibility and is symbolised by blackness and emptiness. Baudelaire's melancholic poetry appears as a poetry about poetry, a poetry that is paradoxical in the sense that it contradicts stillness, acedia, and creative stagnation, while retaining its negative dimension, rising up against itself.

Słowa kluczowe: Charles Baudelaire, melancholia, spleen, czerń, estetyka przemijającego piękna, écriture mélacolique

Keywords: Charles Baudelaire, melancholy, spleen, blackness, aesthetics of transient beauty, écriture mélacolique

* Praca naukowa finansowana w ramach programu Ministra Nauki i Szkolnictwa Wyższego pod nazwą „Narodowy Program Rozwoju Humanistyki” w latach 2016-2021 (Nr 0046/NPRH4/H2a/83/2016). Artykuł jest fragmentem większej całości, która złoży się na książkę Sytuacja Norwida - sytuacja Baudelaire'a, przygotowywaną w serii Horyzonty Nowoczesności. Na temat melancholii Baudelaire'a zob. też dopełniający artykuł: M. Siwiec, , Czarna przędza” Baudelaire’a, „Poznańskie Studia Polonistyczne. Seria Literacka” 2020, nr 37, s. 211-230. 


\section{Dwie melancholie}

Można postawić tezę, że są dwie melancholie Charles'a Baudelaire'a. Pierwsza - wartościowana wyraźnie negatywnie, związana z samozwrotnością i bezpłodnością poetycką; druga - twórcza, odsyłająca do jego koncepcji ułomnego piękna, odzwierciedlająca i wyzyskująca artystycznie cierpienie ${ }^{1}$. Oczywiście rozróżnienie na melancholię „czarną”, bliską acedii, i „białą”, czynną, związaną z geniuszem, funkcjonuje w kulturze od starożytności², u Baudelaire'a dochodzi jednak do pewnych przesunięć. Rodzaj melancholii krytykowany przez pisarza należy do przeszłości, do odchodzącej literatury, jest poddaną już utekstowieniu pozą. Natomiast melancholia drugiego typu, twórcza, należy do teraźniejszości, wiąże się z diagnozą współczesności (co nie oznacza odrzucenia tradycji, a raczej jej dekonstrukcję). Jakie jest $\mathrm{w}$ tej klasyfikacji miejsce spleenu, któremu Baudelaire nadał własne i wyjątkowo skutecznie utrwalone w kulturze oblicze? Margery Skagen stawia mocną tezę, że spleen jest u Baudelaire'a przeciwstawiony melancholii, oznacza bowiem całkowitą inercję, melancholia zaś związana jest z wyobraźnią twórczą, nieskończonością, pięknem, ma zatem konotacje pozytywne ${ }^{3}$.

${ }^{1}$ To rozróżnienie pod wieloma postaciami powraca w badaniach nad twórczością Baudelaire'a. Jean Starobinski pokazuje różnicę między marzeniem a marzycielstwem u Baudelaire'a, zob. idem, Atrament melancholii, przeł. K. Belaid, Gdańsk: słowo/obraz terytoria 2017, s. 312. Patrick Labarthe z kolei wprowadza rozróżnienie na melancholię quasi-szczęśliwą, która animuje wysiłek odnowienia jedni przez metaforę, oraz melancholię tragiczną, która wyostrza pamięć spleenu (jej uprzywilejowanym sposobem wyrazu jest alegoria). Sugeruje on przeciwstawienie spleenu i ennui; zob. idem, Spleen et création poétique dans «Les Fleurs du Mal » [w:] Poètes du spleen. Leopardi, Baudelaire, Pessoa, éd. P. Daros, Paris: Honoré Champion 1997, s. 152.

${ }^{2}$ Zob. P. Dandrey, Anthologie de l'humeur noire. Écrits sur la mélancolie d'Hippocrate à l' "Encyclopédie ", Paris: Gallimard 2005, s. 36; R. Klibansky, E. Panofsky, F. Saxl, Saturn i melancholia. Studia z historii, filozofii, przyrody, medycyny, religii oraz sztuki, przeł. A. Kryczyńska, Kraków: Universitas 2009, s. 271-282. Marek Bieńczyk pisze o melancholii zamykającej się w petryfikującej rozpaczy oraz o melancholii czynnej, twórczej, działającej; zob. idem, Oczy Dürera. O melancholii romantycznej, Warszawa: Sic! 2002, s. 17-18. Oczywiście można uznać za Julią Kristevą, że to ta sama melancholia o dwoistym działaniu: ,jeśli utrata, żałoba, nieobecność umożliwiają pracę wyobraźni, którą tyleż nieprzerwanie podsycają, co jej zagrażają i ją niszczą, znamienne jest również, że to na nieuznaniu tego unieruchamiającego smutku wznosi się fetysz dzieła"; eadem, Czarne stońce. Depresja i melancholia, przeł. M.P. Markowski, R. Ryziński, wstęp M.P. Markowski, Kraków: Universitas 2007, s. 10-11.

${ }^{3}$ Według Skagen dwa aspekty melancholii Miltona, L'Allegro i Il Penseroso (radość i ból), rozdzielają się u Baudelaire'a na melancholię i ennui. Zob. eadem, Ennui vs mélancolie [w:] «Les Fleurs du mal ». Acte du colloque de la Sorbonne de 10 et 11 janvier 2003, éds. A. Guyaux, B. Marchal, Paris: Presses de l'Université de Paris-Sorbonne 2003, s. 250. Zob. też: G. Froidevaux, Baudelaire. Représentation et modernité, Paris: José Corti 1989. Badacz wskazuje na opozycję spleenu i melancholii. 
Sprawa nie jest chyba jednak tak oczywista, a skontrastowanie spleenu z melancholią tak proste. Słusznie dowodzono, że u źródeł spleenu Baudelaire'a leży niezgoda na hiatus między rzeczywistością a ideałem i jest to niewątpliwie dziedzictwo romantyzmu, a nawet jeszcze myśli Friedricha Schillera4 ${ }^{4}$ Oczywiście pierwotnie spleen, oznaczający śledzionę, źródło czarnej żółci, stanowił także pewien typ melancholii wywołanej przez nadmiar owej substancji. Piotr Śniedziewski dowodzi przekonująco, że Baudelaire oderwał pojęcie spleenu od jego najwcześniejszego, związanego z anatomią i utrwalonego przez kulturę angielską znaczenia: „Dla autora Kwiatów zła spleen nie ma już wymiaru somatycznego; to dość abstrakcyjny, niczym nieumotywowany stan uczuciowej zapaści, smutek prowadzący do odrętwienia"s. A zatem jeśli warianty melancholii odrzucone przez Baudelaire'a to warianty inercyjne, prowadzące do petryfikacji twórczej aktywności, spleen z pozoru właśnie do nich należy. Jeśli jednak weźmiemy pod uwagę poematy ze spleenu zrodzone (a nawet spleen noszące w tytule), to samo ich istnienie może świadczyć o aktywnym przetworzeniu, a więc o możliwości twórczej artykulacji, której spleen miałby być zaprzeczeniem. To pierwsza wątpliwość dotycząca tezy Skagen.

Druga związana jest z przypisaniem wyśmianego, odrzuconego przez Baudelaire'a typu melancholii do kultury minionej czy mijającej (romantycznej). Tymczasem spleen jest formą melancholii w ujęciu Baudelaire'a nieodłącznie związaną z nowoczesnością, postępem, życiem metropolii, formą choroby wieku' ${ }^{6}$ Pisarz utożsamił go $\mathrm{z}$ doświadczeniem wielkomiejskim jego spleen jest przecież ,paryskim spleenem”, ideałowi przeciwstawiona jest rzeczywistość nosząca piętno postępu, zurbanizowana - można zatem powiedzieć, że w wariancie Baudelaire'owskim spleenu chodzi o nowoczesną formę melancholii. Charakterystyczne dla melancholika odwrócenie się od teraźniej-

${ }^{4}$ Zob. P. Śniedziewski, Spleen - dialog anatomii z psychologia. Problemy recepcji i przekładu, „Rocznik Komparatystyczny” 2010, nr 1, s. 106. Autor pisze o ewolucji (od rozumienia anatomicznego po psychologiczne, oznaczające ból istnienia) i redefinicji pojęcia spleenu, wymienia poprzedników Baudelaire'a i wskazuje, jak pojęcie spleenu trafiło do twórczości poety. Na temat czarnej żółci i dążenia do „materializacji” melancholii zob. M. Bieńczyk, Melancholia. O tych, co nigdy nie odnajda straty, Warszawa: Sic! 1998, s. 15-20. O spleenie Baudelaire'a jako nowoczesnej melancholii opartej na poczuciu utraty ideału i jego związku z miastem zob. też: J.-M. Maulpoix, Le spleen baudelairien: une melancholie moderne [w:] Poétiques du néant. Leopardi, Baudelaire, Pessoa, éds. B. Didier, D. Levy-Bertherat, G. Ponnau, Paris: CDU-Sedes 1998, s. 23-24; F. Wilhelm, Baudelaire. L'écriture du narcisme, Paris: L'Harmattan 1997 (na s. 15-17 teza, że Rzeczą, o której utracie pisze Kristeva, jest u Baudelaire'a Ideał).

5 P. Śniedziewski, Spleen - dialog anatomii..., s. 123.

${ }^{6}$ Zob. J.-M. Maulpoix, op.cit., s. 26. Zjawiska związane z nowoczesnością, o których pisze badacz w odniesieniu do twórczości poety, to: autonomizacja sztuki, depersonalizacja, wyobraźnia, eksploracja nowych miejsc i form piękna, dysonans, niezgodność, rozdział piękna i prawdy, szukanie dziwności (to też oznacza przejście od melancholii do spleenu). 
szości u Baudelaire'a dokonuje się w samym jej centrum. W najbardziej skrajnych przypadkach prowadzi ono do petryfikacji czasu, jego zwielokrotnienia, zatrzymania ponawiającego nieustanny zgrzyt, potęgującego ból. Oba zbiory poety przedstawiają melancholię jako chorobę nowoczesności. Jej najbardziej emblematycznym przykładem jest $Ł a b e ̨ d z ́(L e C y g n e$ ) - po wielekroć, najlepiej bodaj przez Jeana Starobinskiego, interpretowany ${ }^{7}$ - zwłaszcza zaś słowa: „Paryż się zmienia! Lecz trwa w smutku mego glorii!” („Paris change! mais rien dans ma mélancolie / N'a bougé!") ${ }^{8}$. Zaznacza się tu mocno świadomość nienadążania za zmianami, unieruchomienia we własnym ,ja" podmiotu rozmyślającego o wygnańcach - tych wymienionych w wierszu (z jego adresatem, Victorem Hugo, na czele) i „o innych jeszcze” - który nie może zatrzymać ciągu enumeracji. W Łabędziu dotkniętych ową chorobą łączy jedno - paradoksalne przywiązanie do smutku, bólu (porównanego w wierszu do matki-wilczycy), który nie traci swego destrukcyjnego charakteru. To właśnie w tym liryku znajduje się słynna definicja melancholików jako „tych, co nigdy, nigdy nie odnajdą straty” (,À quiconque a perdu ce qui ne se retrouve / Jamais, jamais!"; KZ, M. Jastrun, s. 230, 231). Chodzi więc o ową utratę nienazwaną, a wciąż nazywaną, stratę, pustkę, przepaść zasypywaną bez końca9.

Do melancholii jako zagadnienia estetycznego Baudelaire wraca raz po raz (również, choć nie tylko, w sposób prześmiewczy), naśladując - jak pisze Starobinski - jej mechanizmy ${ }^{10}$, a przede wszystkim doceniając jej ułomne, bo związane z cierpieniem, piękno. Tak dzieje się w rozważaniach dotyczących malarstwa Eugéne'a Delacroix, których znaczenia dla koncepcji estetycznych poety nie sposób przecenić. W jego obrazach pisarz dostrzega melancholię w doborze tematów, ekspresji postaci, geście, stylu i kolorze. Stawia romantyka obok - stanowiących dla Delacroix bezpośrednią inspirację - Dantego i Szekspira jako „wielkich malarzy cierpienia ludzkiego”"1. Samo to zestawienie dowodzi, że Baudelaire'owskie eseje o malarstwie nie odnoszą się

${ }^{7}$ Zob. J. Starobinski, La Mélancolie au miroir. Trois lectures de Baudelaire, Paris: Julliard 1989, rozdz. 3; M. Bieńczyk, Melancholia..., s. 5-14; idem, Oczy Dürera..., s. 277-278; P. Śniedziewski, Spoglądać w zmacone zwierciadło (Baudelaire) [w:] idem, Melancholijne spojrzenie, Kraków: Universitas 2011, s. 206-211.

${ }^{8}$ Ch. Baudelaire, Le Cygne / Łabędź, przeł. M. Jastrun [w:] idem, Kwiaty zła, wybór M. Leśniewska, J. Brzozowski, posłowie J. Brzozowski, Kraków: Wydawnictwo Literackie 1994, s. 230-231. Wszystkie cytaty z Kwiatów zła w obu wersjach za tym dwujęzycznym wydaniem. Dalej w tekście stosuję skrót: KZ, podając numery stron i tłumacza na język polski.

9 Zob. S. Freud, Żałoba i melancholia [w:] idem, Psychologia nieświadomości, przeł. R. Reszke, Warszawa: KR 2007, zwł. s. 147-149.

${ }^{10}$ J. Starobinski, Atrament..., s. 346.

${ }^{11}$ Ch. Baudelaire, Salon 1846 [w:] idem, Rozmaitości estetyczne, wstęp i przekł. J. Guze, przyp. i koment. C. Pichois, przeł. J.M. Kłoczowski, Gdańsk: słowo/obraz terytoria: 2000 , s. 96. 
wyłącznie do sztuk plastycznych, ale także do literatury. Co jednak istotniejsze, to właśnie owa melancholia jest dla krytyka wyznacznikiem nowoczesności - tym, co czyni z Delacroix prawdziwego malarza XIX wieku. W jakim sensie? Odpowiedź dotyczy zarówno przedmiotu dzieła sztuki, jak i sposobu jego przedstawienia. Otóż Delacroix nie maluje, zdaniem Baudelaire'a, kobiet ładnych, a wartość estetyczna jego portretów wynika właśnie z koniecznej skazy, kobiety z jego płócien bowiem ,[n]iemal wszystkie są chore i promieniuje $\mathrm{z}$ nich jakaś uroda wewnętrzna" 12 . Ten rodzaj melancholii, nazwany „wzniosłym i poważnym” (podobnie jak ,głęboka melancholia” malarstwa Théodore'a Rousseau ${ }^{13}$ ), jest zapewne czymś innym niż ten wynikający z ,romantycznego kręćka"14 i chyba czymś innym niż spleen. $Z$ taką samą estymą jak o Delacroix jako piewcy piękna chorobliwego w odniesieniu do literatury XIX-wiecznej poeta będzie pisał o Byronie, Tennysonie, Poem i ich „,melancholijnym niebie nowoczesnej poezji" ${ }^{15}$. Pierwszego z nich przedstawia jako pełnego wad, które czynią z niego wielkiego poetę. Jest to refleksja stanowiąca pretekst do wygłoszenia credo Baudelaire'a, zgodnie z którym melancholia zawsze towarzyszy poczuciu piękna ${ }^{16}$. Te idee powracają w Racach, gdzie pisarz - ponownie odwołując się do przykładu kobiecej twarzy - formułuje własną koncepcję piękna nowoczesnego, koniecznie zawierającego element nieszczęścia, a melancholię nazywa nieodłączną towarzyszką piękna tak właśnie rozumianego. Oto początek tej definicji:

Znalazłem definicję Piękna - mojego Piękna. To coś, co jest żarliwe i smutne, a także trochę niejasne, otwierające pole domysłom. Pozwólcie, że odniosę swe przemyślenia do obiektu obdarzonego czuciem, obiektu najciekawszego w świecie, mianowicie kobiecej twarzy. Głowa urzekająca i piękna, kobieca oczywiście, to głowa skłaniająca do marzeń, w których rozkosze mieszaja się mgliście ze smutkiem; wionąca melancholią, znużeniem, nawet przesytem - bądź też, przeciwnie,

12 Ibidem, s. 97.

${ }_{13}$ Zob. ibidem, s. 137. Docenia też Josepha Jeannota, którego obraz przypomina mu Melancholię Dürera. Temu słynnemu miedziorytowi nie poświęca osobno uwagi, choć niewątpliwie go ceni, przywołując raz po raz jako przykład arcydzieła. Poddaje za to krytyce analizę Melancholii dokonaną przez Julesa Micheleta.

${ }^{14}$ To określenie z eseju Baudelaire'a, w którym romantyczna melancholia została ośmieszona, zob. Ch. Baudelaire, Piotr Dupont, przeł. A. Kijowski [w:] idem, Sztuka romantyczna, red. R. Engelking, wstęp A. Kijowski, przyp. i koment. C. Pichois, Gdańsk: słowo/obraz terytoria 2003, s. 65.

${ }^{15}$ Ch. Baudelaire, [List do Juliusza Janin], przeł. T. Swoboda [w:] idem, Sztuka romantyczna, s. 237.

16 Ibidem, s. 239. 
żarem, pragnieniem życia, zmieszanym jednak z resztką goryczy, zrodzonej z wyrzeczeń albo rozpaczy. Inne cechy piękna to żal i tajemnica ${ }^{17}$.

Tę koncepcję piękna Baudelaire'a warto zderzyć ze znaczeniem, jakie ma dla poety moda, którą Walter Benjamin nazywa „niestrudzoną agentką treści świadomości fałszywej”"18 i krytyką kultu nouveauté ustanawiającej nowy kanon sztuki. W dualistycznej (łączącej to, co wieczne, z tym, co czasowe) koncepcji piękna wyrażonej w Malarzu życia nowoczesnego, gdzie znajduje się osobny rozdział poświęcony dandysowi, moda należy właśnie do tego, co zależne od okoliczności i co oddaje fenomen teraźniejszości. Autor Kwiatów zła pisze o poszukiwaczu nowoczesności w ogóle (a o Constantinie Guysie w szczególności): „Z mody chciałby wydobyć wszystko, co poetycznego zawiera w historycznym, wieczne odsłonić w przemijającym" ${ }^{\prime 1}$. Moda zostaje uznana „za objaw upodobania do ideału” i „wzniosłą deformację natury” ${ }^{20}$. To, co naturalne, nie jest bowiem zdaniem poety dobre - moralność to rezultat kunsztu, sztuki, kultury, podobnie jak moda właśnie. Tym samym Baudelaire zaburza proste Roussowskie opozycje. Cechą mody jest zatem i nowość, i zmierzanie do ideału piękna (to samo usprawiedliwia, a nawet legitymizuje sztukę makijażu), co pozwala pisarzowi z dandysa (tworzącego modę, ale przeciwnego jej demokratyzacji) uczynić bohatera nowoczesności ${ }^{21}$. Wedle formuły Antoine'a Compagnona Baudelaire jest przy tym pisarzem antynowoczesnym, sytuującym się w centrum postępu, który poddaje krytyce ${ }^{22}$.

${ }^{17}$ Ch. Baudelaire, Race [w:] idem, Sztuczne raje, wstęp i przekł. R. Engelking, przyp. i koment. C. Pichois, Gdańsk: słowo/obraz terytoria 2009, s. 349.

18 W. Benjamin, Paryż - stolica dziewiętnastego wieku [w:] idem, Twórca jako wytwórca. Eseje i rozprawy, przeł. R. Reszke, Warszawa: KR 2011, s. 330.

${ }_{19}$ Ch. Baudelaire, Malarz życia nowoczesnego [w:] idem, Rozmaitości..., s. 319.

${ }^{20}$ Ibidem, s. 339.

${ }^{21}$ Baudelaire pisze: „Dandyzm to zachodzące słońce; jak spadająca gwiazda jest wspaniały, bez żaru i pełen melancholii"; ibidem, s. 335. O dandyzmie Baudelaire'a w kontekście melancholii zob. J. Starobinski, La Mélancolie au miroir..., rozdz. 1. Na ten temat zob. też: Z. Markiewicz, Teologia ubioru? O poszukiwaniu sacrum w powierzchowności stroju. Baudelaire'owska koncepcja mody XIX wieku a widzenie szat (liturgicznych) przez Nowosielskiego, „Humanistyka i Przyrodoznawstwo” 2011, nr 17, s. 332-336. M. Foucault pisze o dandyzmie Baudelaire'a jako heroizowaniu teraźniejszości; zob. idem, Czym jest Oświecenie? [w:] idem, Filozofia, historia, polityka. Wybór pism, przekł. i wstęp D. Leszczyński, L. Rasiński, Warszawa-Wrocław: PWN 2000, s. 284. G. Froidevaux stwierdza, że dla Baudelaire'a moda jest jednocześnie ekspresją i negacją nowoczesności, obietnicą nowości wiecznej, a zatem niemożliwej; zob. idem, op.cit., s. 9-12, 77-106.

${ }_{22}$ Zob. A. Compagnon, Les antimodernes de Joseph de Maistre à Roland Barthes, Paris: Gallimard 2005. Zob. też wykłady Compagnona w Collège de France na temat stosunku Baudelaire'a do fenomenów nowoczesności (w których miałam przyjemność uczestniczyć w 2012 roku), dostępne na stronie: https://www.college-de-france.fr/site/antoine-compagnon/course-2012-01-10-16h30.htm [dostęp: 15.12.2020]. Bardziej odpowiednia wydaje mi się przy tym formuła amodern wprowadzona przez Josepha Acquisto, oddająca ambiwalentny stosunek pisarza do nowoczesności; zob. idem, The Fall out of Redemption. Writing 
W tym miejscu warto zwrócić uwagę na ważny aspekt Baudelaire'owskiej melancholii związany z jej wymiarem estetycznym. Poeta przypisuje ją bowiem zarówno obiektom (jak owym przedstawianym przez malarza kobietom), jak i - co istotniejsze - samemu artyście. To bowiem on właśnie patrzy na świat w specyficzny, ,skażony” sposób, wyszukując to, co zranione, pęknięte, niedoskonałe; to w jego spojrzeniu ma swoje źródło dotknięte chorobą dzieło. Ta perspektywa ujawnia się wyraźnie także w Kwiatach zła, w których Pierre Dufour odnajduje aż cztery nakładające się na siebie, związane z melancholią dyskursy: nowoczesnej psychiatrii, psychoanalizy freudowskiej, historyczno-kulturowy i metadyskurs melancholijny ${ }^{23}$. Kwiaty zła to fleurs maladives, „kwiaty chorobliwe" 24 , eksponujące doświadczenie podmiotu wierszy i wpisanego w nie czytelnika właśnie jako chorobliwe, prowadzące do odkrycia nowej jakości estetycznej, ułomnego piękna.

\section{Czarne słońca}

W tym artykule skupię się przede wszystkim na paradoksalnej metaforyce świetlistej czerni (a zatem nie prostej opozycji światła i ciemności), którą poeta wyzyskuje w utworach o charakterze metatekstowym. W De profundis clamavi Baudelaire idzie w ślady Gérarda de Nervala jako autora El Desdichado, tyle że słynne „czarne słońce Melancholii” z sonetu Nervala zastępuje „soleil sans chaleur” (słońce pozbawione ciepła, „słońce bez żaru”) i - również oksymoroniczne - „soleil de glace” („słońce z blaski lodowemi”; KZ, S. Korab-Brzozowski, s. 84, 85 ${ }^{25}$. Kiedy Baudelaire to pisze, metafora czar-

and Thinking beyond Salvation in Baudelaire, Cioran, Fondane, Agamben, and Nancy, New York-London: Bloomsbury 2015, s. 11. Piszę o tym także w: M. Siwiec, Norwid, Baudelaire i reguty sztuki, „Teksty Drugie” 2020, nr 5.

${ }_{23}$ Zob. P. Dufour, "Les Fleurs du Mal »: dictionnaire de mélancolie, „Littérature” 1988, no 4: Matière de poésie, s. 32. Badacz odnajduje u Baudelaire'a ślady melancholia artificialis, którą Erwin Panofsky wyczytuje z dzieła Dürera. Dufour dowodzi, że u poety Melancholia jawi się jako towarzyszka Piękna i nowoczesności zarazem oraz jako przedmiot dyskursu, na który w istocie składa się kilka dyskursów. Badacz czyta bowiem Les Fleurs du Mal jako tekst troisty: tekst kliniczny, tekst kultury i tekst poetycki.

${ }^{24}$ D. Oehler podkreśla, że tytuł - nawet ten ostateczny: Kwiaty zła - nie jest wcale niewinny, jak chciał przekonać Baudelaire, wskazuje bowiem na pewną chorobliwość; zob. D. Oehler, Le Spleen contre l'oubli, juin 1848: Baudelaire, Flaubert, Heine, Herzen, Paris: Payot e Rivages 1996, s. 288. Badacz dowodzi także, że w melancholii Baudelaire'a zawsze jest jakiś element rewolucyjny, element walki (s. 300).

${ }_{25}$ Zob. J. Kristeva, op.cit., passim, zwł. rozdz. Nerval, „El Desdichado”. Mario Richter obraz słońca z lodu odnosi do sztuki bez życia, pięknej, lecz zimnej, zob. idem, Baudelaire, "Les Fleurs du mal ». Lecture intégrale, Genève: Slatkine 2001, t. I, s. 283. Zob. też: M. Quesnel, Baudelaire solaire et clandestin, Paris: Presses Universitaires de France 
nego słońca jest już mocno utrwalona w kulturze, pojawi się ona zresztą dosłownie w Paryskim spleenie. W Kwiatach zła poeta skupia się na opozycji termicznej bardziej niż wizualnej - kolorystycznej. Stałą cechą tej poezji jest zbliżenie czerni, mrozu, lodu, jak w Piosence popoludniowej (Chanson d'après-midi), w której mowa o „noire Sibérie” - Syberii nie białej, a właśnie czarnej. Co ważne, Syberia opatrzona jest zaimkiem dzierżawczym „moja” („,mój czarny Sybir”; KZ, J. Waczków, s. 160, 161). Zimno i czerń lub mrok jawią się w tym ostatnim wierszu, choć nie tylko w nim (np. „froides ténèbres” w Pieśni jesiennej / Chant d'automne czy „un froid ténébreux” w Lubię wspomnienie... / J'aime le souvenir...), jako właściwości pokrewne - obie określające podmiot. Ich wspólną cechą jest brak, stanowią przeciwieństwo czy zaprzeczenie wartości umożliwiających życie: światła i ciepła. To pokrewieństwo wprost określi Baudelaire w Sztucznych rajach, pisząc o percepcji mroku: „ciemność, wrażenie, jak sądzę, związane z uczuciem zimna”"26.

W całym zbiorze Kwiatów zła powracają obrazy słońca przesłoniętego, zakrytego kirem, czarną krepą, jak w Opętanym / Le possedé („Kir przysłonił już słońce” / „Le soleil s'est couvert d'un crêpe”; KZ, B. Wydżga, s. 98, 99) czy w Karze za pychę / Châtiment de l'orgueil („To słońce wnet przyćmiła żałobna powłoka” / „L'éclat de ce soleil d'un crêpe se voila”; KZ, C. Jastrzębiec-Kozłowski, s. 4, 49), słońca zamglonego, schowanego za chmurami, zachodzącego (Staruszeczki / Les Petites Vieilles, Skupienie / Recueillement, Wróg / L’Ennemi, Zasnute niebo / Ciel brouillé, Harmonia wieczorna / Harmonie du soir, Zaproszenie do podróży / L'Invitation au voyage, Pieśń jesienna / Chant d'automne, Puchacze / Les Hiboux, Rycina fantastyczna / Une gravure fantastique, Zasnute niebo / Ciel brouillé, Spleen II [Więcej mam wspomnień... / J'ai plus de souvenirs...], Miłość kłamstwa / L'Amour du mensonge, Powrotność / Réversibilité). Eksponują one inwazję mroku, ale wciąż wartościując pozytywnie słoneczne światło, którego utrata czy redukcja odczuwana jest jako brak. Co więcej, brak czy osłabienie działania słońca jest dla Baudelaire'a ściśle związane z melancholią. W Puchaczach (Les Hiboux) godzina przesłonięcia słońca przez ciemności nazwana jest wprost „godziną [...] melancholijną" (,„'heure mélancolique”; KZ, J. Brzozowski, s. 180, 181). W całym zbiorze, począwszy od Błogosławieństwa (Bénediction), gdzie

1987. Michel Quesnel, przyjmując perspektywę psychoanalityczną, z wyobraźnią solarną Baudelaire'a wiąże jego relacje z ojcem (obecnym zawsze mimo śmierci) i z matką (brak ciepła - brak miłości macierzyńskiej), a także z chorobą Jeanne Duval (s. 173-177). Warto wspomnieć najważniejsze utwory literackie potwierdzające karierę metafory czarnego słońca w literaturze romantycznej: Ciemność George'a Byrona (thumaczoną przez Adama Mickiewicza), Mowę wypowiedziana przez umarłego Chrystusa ze szczytu kosmicznego gmachu o tym, że Boga nie ma Jean Paula, rozpowszechnioną w Europie za sprawą Madame de Stäel, katastroficzne, wizyjne utwory Zygmunta Krasińskiego czy Nie-Boska komedię tegoż.

${ }^{26}$ Ch. Baudelaire, Sztuczne raje. Opium i haszysz [w:] idem, Sztuczne raje, s. 68. 
poeta „wyrzutek słońca blask pije bez miary” („L'Enfant déshérité s’enivre de soleil"; KZ, I. Kania, s. 10, 11), można znaleźć przywołania słońca jako wartości utraconej, należącej do minionego szczęśliwego dzieciństwa jednostki lub całej ludzkości (Lubię wspomnienie... / J'aime le souvenir..., Poprzednie wcielenie / La Vie antérieure, Olbrzymka / La Géante, Zapach egzotyczny / Parfum exotique, Warkocz / La Chevelure, Do Kreolki / À une dame créole, Wróg / L'Ennemi, Kara za pychę / Châtiment de l'orgueil, Balkon / Le Balcon, Pieśń jesienna / Chant d'automne), wartości przywracanej na krótko w momentach epifanicznych ${ }^{27}$. Opozycję między słońcem, światłem a czernią związaną z melancholią ukazuje Baudelaire w Podróży na Cyterę (Un voyage à Cythère) - promienne słońce i jasność określające stan podmiotu to punkt wyjścia podróży w stronę postępującego rozczarowania i odczarowania świata zarazem $^{28}$. Wyłaniająca się na horyzoncie wyspa jest „,smutna i czarna” (,triste et noire"; KZ, J. Waczków, s. 304, 305) i ta czerń dokonuje tu inwazji oraz eskaluje przygnębienie - aż po uznanie pejzażu z wisielcem za alegorię ,ja”:

Choć morze błękitniało w jaśnieniu podniebnym,

Dla mnie się krwią i czernią zasnuła toń cała

W chwili, gdy mi Cytera serce pogrzebała

W tej strasznej alegorii jak w całunie zgrzebnym.

- Le ciel était charmant, la mer était unie;

Pour moi tout était noir et sanglant désormais,

Hélas! et j'avais, comme en un suaire épais,

Le coeur enseveli dans cette allégorie. (KZ, J. Waczków, s. 306, 307)

Baudelaire rozwija w wierszu również somatyczną koncepcję melancholii. Nagle zalewająca podmiot fala żółci i mdłości to nie tylko reakcja na widok trupa, ale także skutek otwarcia rany (poruszenia „czarnej żółci”), rozpoznania w sobie bólu prowadzącego do identyfikacji z profanowanym przez zwierzęta ciałem. Ta identyfikacja to znak rozbicia podmiotowej tożsamości.

Centralna dla melancholii metafora czarnego słońca - przybierająca u Baudelaire'a (jak w De profundis clamavi) także formę słońca z lodu - niesie ze sobą nową jakość, przekraczającą proste przeciwstawienie światła i ciem-

${ }^{27}$ O tym słońcu jako znaku utraty traktuje książka P. Śniedziewskiego, Czarne słońca romantyków, Warszawa: Sic! 2018. Poznański badacz analizuje również bardziej szczegółowo poemat prozą Pragnę malować, przywołany przeze mnie niżej. Zob. też: P. Dufour, op.cit., s. 39-40 (tu o figurze odwrócenia i kontrastu w rodzaju „czarnego słońca” Nervala i Hugo u Baudelaire'a, a także o języku à rebours, jakim próbuje się wyrazić melancholia).

${ }^{28}$ O postępie tego rozczarowania w zestawieniu z ujęciem Nervala zob. B. Sosień, Francuski romantyk na wyspach greckich [w:] Dziedzictwo Odyseusza. Podróż, obcość i tożsamość, identyfikacja, przestrzeń, red. M. Korytowska, O. Płaszczewska, Kraków: Universitas 2007, s. 141-156. 
ności. Widać to doskonale w Paryskim spleenie, gdzie „czarne słońce” przywołane jest wprost, czy w poemacie Le désir du peindre (Pragnę malować), najwyraźniej eksponującym metapoetycki charakter odwołań do malarstwa:

Jest piękna, więcej niż piękna: jest zdumiewająca. Dominuje w niej czerń i wszystko, co budzi, jest mroczne i niezgłębione. Jej oczy to jaskinie, w których niejasno migocze tajemnica, a jej spojrzenie oślepiające jak błyskawica, to eksplozja w ciemnościach.

Porównałbym ją do czarnego słońca, gdybyśmy mogli wyobrazić sobie czarną gwiazdę siejącą blask i szczęście. Ale raczej przywodzi na myśl księżyc, który naznaczył ją niechybnie swoim okrutnym piętnem; nie idylliczny biały księżyc podobny do zimnego oblubieńca, lecz księżyc złowróżbny i upojny, wiszący w głębinach burzliwej nocy, szarpany przez rozpędzone chmury $[\ldots]^{29}$.

O metaforze Nervala pisano, że stanowi przeniesienie na obrazy astralne stanu wewnętrznego przygnębienia, symbol wewnętrznej apokalipsy, zniszczenia duszy $^{30}$. Julia Kristeva twierdzi, że Nervalowskie czarne słońce „podejmuje pole semantyczne «ciemności», ale wywraca je niczym rękawicę: cień wytryskuje słoneczną jasnością, która jednakże wybucha czarną niewidzialnością?"31. Taki destrukcyjny charakter mają także obrazy Baudelaire'a, który będzie eksponował obie strony tego oksymoronu: czarne słońce jest czarne, ale jest wciąż słońcem. Przedstawiona w poemacie piękność to piękność mroczna i podlegająca skażeniu, w czym przypomina opisane w Salonach melancholijne kobiety z obrazów Delacroix. Czarne słońce - czarna gwiazda - w tekście Baudelaire'a pojawia się jako element porównania, i to taki, którego wyobrażenie podane jest $\mathrm{w}$ wątpliwość, ma więc charakter podwójnie hipotetyczny. Niemniej nie chodzi już w tym przypadku o wartość (słońce) przytłumioną czy zagrożoną (czernią, kirem, chmurami), ale o zupełnie nową. Mrok i czerń nie są brakiem światła - promieniują, w czym zachowują właściwość słońca ${ }^{32}$. To ciemność, która jest źródłem, a nie zaprzeczeniem światła, czerń świetlista.

${ }^{29}$ Ch. Baudelaire, Pragne malować [w:] idem, Sztuczne raje, s. 241.

${ }^{30} \mathrm{~B}$. Juden, Traditions orphiques et tendances mystiques dans le romantisme français (1800-1855), Paris: Éditions Klincksieck 1971, cz. 5, rozdz. 6: Les flèches de la lumière. Gérard de Nerval.

${ }^{31}$ J. Kristeva, op.cit., s. 149.

32 Według Géralda Antoine'a u Baudelaire'a zasadniczo niezmiennym tematem jest antytetyczne połączenie światła i ciemności (zob. idem, La Nuit chez Baudelaire, „Revue d'Histoire littéraire de la France" 1967, no 2, s. 392), bez preferowania któregokolwiek z nich. Jego zdaniem poeta nie ogranicza się do kumulowania efektów kontrastowego zderzenia ciemności i światła (na s. 389 są one zresztą skrupulatnie wymienione). W ich współistnieniu w poezji badacz widzi analogię do słynnego zdania Baudelaire'a o ludzkiej egzystencji w każdej chwili rozdartej między Bogiem a szatanem. Wskazuje na fenomen czarnego płomienia, bladych ciemności (,pâles ténèbres”), mroku prowadzącego do światła 
Podobną cechę ma „czarne słońce” w Ustach ciemności (Ce que dit la bouche d'ombre) Victora Hugo: „Un affreux soleil noir d'où rayonne la nuit” (w przekładzie Zbigniewa Bieńkowskiego: „słońce ciemności, czarne źródło nocy" $\left.{ }^{33}\right)$. W Kontemplacjach to z niego promieniuje noc, tyle tylko, że ma ono charakter katastroficzny, związany bardziej z makrokosmosem niż z pejzażem psychicznym (także ten ostatni aspekt jest u Hugo obecny, aczkolwiek w sposób dość szczególny, ,ja” jego późnych poematów rozrasta się bowiem do rozmiarów kosmicznych). U Baudelaire'a, odmiennie niż u Hugo, czarne słońce jest raczej pociągające niż przerażające.

Czarne gwiazdy natomiast przywołane są w Dwoistym pokoju w związku z iluzoryczną, wyobrażoną pięknością, z kontemplacją jej oczu: „Często badałem te czarne gwiazdy wymuszające ciekawość i zachwyt” ${ }^{\prime 34}$. Skonwencjonalizowany komplement - porównanie kobiecych oczu do gwiazd - ulega komplikacji. Dodanie epitetu „czarne” jako określenia oczu-gwiazd jest niepokojące: w naturze bowiem, skąd porównania są zazwyczaj czerpane, czarne gwiazdy nie występują, a jeśli tak - wróżą nieszczęście, są znakiem anomalii, katastrofy. Tak jak w Pragnę malować chodzi tu jednak o fantazmat, ważniejszy jest zatem język, jakim piękność jest opisana, niż mimesis. To język zabarwiony czernią melancholii, świadczący raczej o skażonej wyobraźni podmiotu niż o obiekcie zachwytu czy przedmiocie pożądania.

W Pragnę malować czarne słońce zostaje zastąpione księżycem, ale szczególnym, złowróżbnym. Baudelaire podkreśla jego dwoistość, jak dwoistość melancholii: ten frenetyczny, upojny i burzliwy księżyc przeciwstawiony jest białemu księżycowi idylli. Taka Luna staje się patronką poetów przeklętych, oponentką słońca (Luna melancholijna / Tristesses de la lune, Księżyc urażony / La Lune offensée), szczególnie takiego, do którego Baudelaire ma awersję, bo przecież nie zawsze stanowi ono wartość pozytywną. Myślę tu o zawartych także w Kwiatach zła obrazach słońca rażącego, bezlitośnie eksponującego niedoskonałości, brud, zło świata i w tym sensie okrutnego i niechcianego (Stońce / Le Soleil, Padlina / Une charogne), również dlatego, że tłumiąc wyobraźnię, narzuca tak niemiły Baudelaire'owi mimetyzm w sztuce. Taki obraz słońca występuje zresztą też w Paryskim spleenie, jak choćby na początku Pięknej Doroty (La Belle Dorothée). Egzotyczna piękność staje się w pewnym sensie konkurentką oślepiającego, męczącego i okrutnego słońca. Kiedy

(zwł. s. 384-396). Dla badacza kluczowymi dla tematu Nocy poematami prozą są: Les Fenêtres (Okna), Le Désir de peindre (Pragnę malować), La Chambre double (Dwoisty pokój), Le Crépuscule du soir (Zmierzch) i Anywhere out of the World (s. 399-401).

${ }_{33}$ V. Hugo, Ce que dit la bouche d'ombre [w:] idem, Oeuvres poétiques complètes, éd. F. Bouvet, Paris: J.J. Pauvert 1961, s. 472. Przekład: idem, Usta ciemności [w:] idem, Liryki i poematy, przeł. Z. Bieńkowski, Warszawa: Państwowy Instytut Wydawniczy 1962, s. 77.

${ }^{34}$ Ch. Baudelaire, Dwoisty pokój [w:] idem, Sztuczne raje, s. 171. 
dumnie kroczy, nie tyle „odcina się od światła jaskrawą i czarną plamą”, jak chciałby thumacz, ile „czyni” na świetle czarną i jaśniejącą plamę - „faisant sur la lumière une tache éclatante et noire" 35 .

W Kwiatach zła znaleźć można takie utwory, w których mowa o blasku pozbawionym źródła, jak w Śnie paryskim (Rêve parisien):

Zreszta ani gwiazdy, ni słońca,

Ni zorzy, co by nieba brzaskiem

Oblała te cuda bez końca:

Świeciło wszystko własnym blaskiem!

Nul astre d'ailleurs, nuls vestiges

De soleil, même au bas du ciel,

Pour illuminer ces prodiges,

Qui brillaient d'un feu personnel! (KZ; B. Wydżga, s. 270, 271)

35 Idem, Piękna Dorota [w:] idem, Sztuczne raje, s. 213; idem, La Belle Dorothée [w:] idem, Euvres complètes, texte établi, présenté et annoté par C. Pichois, t. I, Paris: Gallimard 1975, s. 316. Określenie „czarna Wenus”, stosowane przez przyjaciół i matkę Baudelaire'a wobec jego kochanki, Jeanne Duval, nie ma raczej związku z metatekstową metaforą czarnej gwiazdy w jego poezji, lecz odnosi się do ciemnego koloru skóry egzotycznej piękności. Można wskazać przedstawiające ją rysunki i utwory pisarza, do których powstania była inspiracją (wiersze $\dot{A}$ une dame créole, $\dot{A}$ une Malabaraise oraz wspomniany tu poemat prozą La belle Dorothée). Courbet na prośbę poety wymazał jej wizerunek ze słynnego Atelier malarza, istnieje za to jej portret pędzla Édouarda Maneta. Zwróciłabym również uwagę na wiersz poety dedykowany Sainte-Beuve'owi, w którym pojawia się południowa Melancholia oraz określenie „mroczna Wenus” (,sombre Venus”); zob. Ch. Baudelaire, Euvres complètes, s. 207. W Kwiatach zła często występuje oparty na opozycjach (płomienna cielesność i zimne serce) fantazmat kobiety lubieżnej, zmysłowej i w tej zmysłowości zwierzęcej i demonicznej, okrutnej i bezlitosnej. Takie opinie o ,éternel Venus" wracają jeszcze w Racach i w Moim obnażonym sercu, gdzie kobieta (natura) przeciwstawiona jest dandysowi (sztuka), którego własną wersję Baudelaire stworzył w pismach estetycznych. To jednak temat wykraczający poza poetologiczną problematykę tego artykułu, wymagający osobnego opracowania; zob. np. M. Reid, Misogynie de Baudelaire [w:] Masculin / féminin. Le XIXe siècle à l'épreuve du genre, éd. Ch. Bertrand-Jennings, Toronto: Centre d'Études du XIX ${ }^{\mathrm{e}}$ siècle Joseph Sablé 1999. Zob. też: J. Starobinski, La Mélancolie au miroir..., rozdz. 1, gdzie mowa o wspomnianym wierszu do Sainte-Beuve'a (s. 17), a także o melancholii i ironii (s. 31-36). Wątki biograficzne są tu interesujące: wiadomo, że Baudelaire opiekował się chorą już kochanką, niemniej jej portret literacki wpisuje się w tendencję nazwaną przez J. Kristevą „fetyszyzacją kobiety”; zob. J. Bator, Julia Kristeva - kobieta i , symboliczna rewolucja”, „Teksty Drugie” 2000, nr 6. Bohaterką podmiotową, o własnym głosie czyni Jeanne Duval w swoim opowiadaniu A. Carter, Czarna Wenus [w:] eadem, Czarna Wenus. Opowiadania, wybór, przekł., wstęp i przyp. A. Ambros, Warszawa: Czytelnik 2000. 
Brak słońca nie oznacza braku światła. Oznacza inny blask - taki, którego źródło trudno określić i którego wartościowanie nie jest już oczywiste. Również w Widmie (Un Fantôme) powraca obraz uwięzienia we własnym, mrocznym ,ja", a także fantazmat światła chorego, iluzorycznego, blask widma, wcielenia ideału, raz jeszcze „czarnego a jednak jaśniejącego” (,noire et pourtant lumineuse”; A. M-ski thumaczy „chmurna - jednak tak promienna"; KZ, s. 100, 101). Nie ma w tej przestrzeni promienia radosnego, co nie oznacza, że nie ma go wcale. Zastępuje go bowiem właśnie ów mroczny, czarny blask. Światło może też zostać utożsamione ze śmiercią: „Śmierć, kiedy wzniesie się podobna słońcu” („,la Mort, planant comme un soleil nouveau”; Śmierć artystów / La Mort des artistes; KZ, T. Lubelski, s. 328, 329); śmierć „,[t]o błysk jasny nadziei w naszej czarnej doli” („,C'est la clarté vibrante à notre horizon noir"; Śmierć nędzarzy / La Mort des pauvres; KZ, M. Leśniewska, s. 326,327$)^{36}$.

W Świcie duchowym (L'Aube spirituelle), unaoczniającym zderzenie spleenu i ideału, światło i czerń (właśnie czerń, nie proste przeciwieństwo światła, czyli mrok) wchodzą w niepokojącą relację wskutek ,działania tajemnicy mściwej” („,Par l'opération d'un mystère vengeur”; KZ, M. Leśniewska, s. 122, 123) - przebudzenia Ideału w rozpustniku. Nieosiągalne duchowe niebiosa („Nieba Ducha” / „Cieux Spirituels”; KZ, M. Leśniewska, s. 122, 123) pociągają z siłą przepaści człowieka zawieszonego między cierpieniem a marzeniem. Już w samym użyciu liczby mnogiej ujawnia się zabieg podważający podstawowe znaczenia - wielość „duchowych nieb” nie służy podtrzymaniu teleologicznej i spójnej wizji świata, a wręcz przeciwnie - rozbija ją. Podobny rezultat przynosi uznanie ich nieosiągalności. Eskalację - i już całkowite zaprzeczenie ich konstruktywnego wymiaru - stanowi przypisanie im właściwości przepaści. W opisie Bogini - czystego bóstwa reprezentującego ideał, które powraca jako pociągające i zarazem bolesne wspomnienie - elementem porównania jest czarny blask: „Słońce czerni świec płomień” („Le soleil a noirci la flamme des bougies"; KZ, M. Leśniewska, s. 122, 123). Światło słoneczne i światło świecy zdają się ze sobą konkurować, jednak nie poprzez intensywność blasku. Właściwością tego słońca jest nie tyle przyćmiewanie płomyka, ile zarażanie go czernią, czernienie, nadawanie mu cech pierwotnie obcych. Adresatka wiersza przypomina właśnie takie zwycięskie słońce (,l'immortel soleil”). Jest ona jednak jeszcze bardziej iluzoryczna niż bohaterka Pragnę malować. Stanowi przecież odblask, odbicie pragnienia znużonego

36 Zob. P. Dufour, op.cit., s. 42-46. Pisze on także: „Widzieliśmy, jak wielowymiarowy konstrukt zwany «melancholią» uwydatnia w Kwiatach zła negatywne i nocne imaginarium, którego najmroczniejsze wyobrażenia zarysowują rodzaj alegorycznej ontologii podmiotu" (s. 51). O czerni (wpisującej się w czas i śmierć, przepaść skończoności) i mroku u Baudelaire'a jako uduchowionej przez spojrzenie materii fascynującej poetę zob. A. Hirt, Baudelaire. Exposition de la poésie, Paris: Kimé 1998, s. 211-212. 
rozpustnika, spoglądającego na swoje życie jak na ruinę ${ }^{37}$. Jak sądzę, Baudelaire zbliża się w tych miejscach do granic języka, dąży do zanurzenia się w mroku poza tymi granicami, a jednocześnie obstaje przy jaśniejącym, choć bladym zapisie, broniąc go jak twierdzy, ostatniej flanki.

\section{Czarne płótno}

W Opętaniu (Obsession) puszcze, ocean, noc są przywołane wyłącznie poprzez wrażenia, jakie wywierają na ,ja”: lasy przerażają i w ,naszych przeklętych sercach" (w formie liczby mnogiej ujawnia się po raz kolejny zawiązana w otwierającym zbiór wierszu Do Czytelnika / Au Lecteur wspólnota) wywołują echa wiecznej żałoby. W znienawidzonym oceanie także odbija się wewnętrzny stan podmiotu. Wyjaśnienie takiego obrazu świata tkwi, jak w przypadku innych wierszy, w preferencjach ,ja" lirycznego. Tym, czego podmiot świadomie szuka, jest właśnie pustka, czerń i nagość: „A próżni, mroku szuka moja dusza smutna!” („Car je cherche le vide, et le noir, et le nu !”; KZ, S. Korab-Brzozowski, s. 204, 205). Niechęć do światła, a zatem do tego, co znane, jak znana jest mowa gwiazd, to jednocześnie przekleństwo poety i jego wybór:

Jak bym cię kochał, Nocy! bez twych gwiazd miliona,

Bo ich światło to mowa stokroć powtórzona!

A próżni, mroku szuka moja dusza smutna!

Lecz, niestety, ciemności nawet są jak płótna,

Gdzie tysiączne postacie odtwarza me oko

Osób znikłych, lecz tkwiących w pamięci głęboko.

Comme tu me plairais, ô nuit ! sans ces étoiles

Dont la lumière parle un langage connu !

Car je cherche le vide, et le noir, et le nu !

Mais les ténèbres sont elles-mêmes des toiles

Où vivent, jaillissant de mon œil par milliers,

Des êtres disparus aux regards familiers. (KZ, S. Korab-Brzozowski, s. 204, 205)

${ }^{37} \mathrm{Na}$ temat ruin, estetyki fragmentu, całości rozbitej u Baudelaire'a zob. L. Schneider, Symptômes de ruines "fragments d'avenir ", „L'Année Baudelaire” 1998, vol. 4: Postérités de Baudelaire, s. 18-24. 
W ten sposób dokonuje się sublimacja, przetworzenie trwogi w sonet ${ }^{38}$. Można uznać ten wiersz, jak wiele innych „kwiatów zła”, za metapoetycki. Jego przedmiotem jest bowiem właśnie poezja melancholijna - powstająca w opozycji wobec znanego, tu utożsamionego ze światłem języka (,langage connu"), poetyckiej artykulacji, stanowiąca zmierzanie (ta dziwnie złożona konstrukcja gramatyczna dobrze oddaje asymptotyczność, o którą mi tu chodzi) ku wszystkiemu, co takiej poezji przeczy, co znajduje się poza granicami wyrażalności, a symbolizowane jest przez czerń i pustkę. Poezja leżąca całkowicie poza artykulacją jest jednak niemożliwa. Przypomnę, że koncepcja poezji Baudelaire'a znajduje się także na antypodach literatury mimetycznej: natura nie jest naśladowana w wierszu, lecz przeciwnie - nabiera znaczeń wyłącznie ze względu na podmiot, który ją przetwarza w sposób sztuczny, artystyczny. Drzewa, ocean, noc to nie elementy przyrody, które mają cieszyć oko, ale przedmioty lęku i nienawiści. Podmiot wyznaje, że noc podobałaby mu się bez gwiazd, zapewne dlatego, że taka, jaka jest, nie może się podobać, a więc być źródłem doznań estetycznych ${ }^{39}$. Artysta chce przetwarzać rzeczywistość na swój obraz i podobieństwo: noc bardziej czarna korespondowałaby lepiej z czernią ,ja".

W konkluzji sonetu ciemności stają się płótnem - to ważna metafora, wzmacniająca tezę o autoreferencjalnym charakterze wiersza - niejako wbrew woli podmiotu, mimo jego pragnienia, by były pustką, czernią niezapełnioną światłami i obrazami. Znaczące jest rozpoczęcie ostatniej strofy od ,ale” (,mais"), które następuje po wyrażeniu inklinacji do nicości i sygnalizuje jakąś przeszkodę, niemożność realizacji. Istoty, które odeszły już do niebytu, wbrew logice powracają - w oku poety (,„pod okiem pamięci”, jak napisałby Słowacki), w jego artystycznym przetworzeniu. Tym samym właśnie to, co powinno pozostać nicością, zapełnia się w sposób materialny, brak zyskuje wymiar substancjalny. Można więc uznać, że brak staje się źródłem poezji - jak w Spleenie II (o którym pisze Starobinski), gdzie to, co przypisane chorobie melancholii, okazuje się na nią lekarstwem ${ }^{40}$. Ponownie ciemności są epicentrum kreatorskiego wybuchu, w czym można widzieć zapowiedź Baudelaire'owskich wariantów metafory czarnego słońca, o której była już

${ }^{38}$ O sublimacji jako strategii panowania nad Rzeczą pisze J. Kristeva, op.cit., np. s. $17-18,25-29$.

${ }^{39}$ Fantazmat erotyczny ciemnej nocy bez gwiazd pojawia się w Obietnicach twarzy (KZ, B. Wydżga, s. 412, 413). Na temat awersji Baudelaire'a do natury, do wszystkiego, co płodne, zmierzające do rozmnożenia, a zatem powielenia tego, co jednostkowe, rozumienia twórczości jako kreacji przeciw naturze, zob. J.-P. Sartre, Baudelaire, przeł. K Jarosz, przedm. M. Leiris, posłowie P. Małochleb, Kraków: Zielona Sowa 2007, s. 23, 70-77.

${ }^{40}$ Zob. J. Starobinski, Atrament..., s. 327. Zdaniem badacza w Pociagajacej grozie bezbożnik zapełnia pustkę, „osiąga pełnię bytu substancjalnego w czystej substancji Zła” (s. 344). 
mowa. Noc jako źródło poetyckiego światła (ciemności stającej się światłem) to koncept wykorzystany także później w Paryskim spleenie - zwłaszcza w Zmierzchu (Le Crépuscule du soir):

Noc, która swą ciemność sączyła w ich mózgi, w mój wnosi światło; i choć nierzadko widuje się przeciwne skutki płynące z tej samej przyczyny, jest w tym coś, co mnie intryguje i niepokoi.

O nocy! rzeźwiąca ciemności! dla mnie jesteś zwiastunką wewnętrznego święta, jesteś wyzwoleniem od lęków!11

Metafora malowania na płótnie ciemności jest Baudelaire'owskim leitmotivem metapoetyckim - czy nawet szerzej, autoreferencjalnym, dotyczącym kreacji artystycznej i wyobraźni twórczej - której analogię znajduje poeta w procesach wizji narkotycznych. Pisząc o Wagnerze, Baudelaire stwierdza:

Słuchającemu tej żarliwej i despotycznej muzyki wydaje się niekiedy, iż ma do czynienia z przyprawiającymi o zawrót głowy opiumicznymi majaczeniami, od malowanymi na tle spowijającego wszystko mroku (,peintes sur le fond des ténèbres"), rozdartego przez marzenie ${ }^{42}$.

Symptomatyczne i logiczne wydaje się, że podobny obraz pojawia się w Opium $i$ haszyszu ze Sztucznych rajów, gdzie mowa o wyobraźni i zdolnościach kreacyjnych dzieci malujących wizje „sur la toile féconde des ténèbres”, mających „osobliwą zdolność - na płodnych płachtach mroku potrafią dostrzec, czy też stworzyć, świat dziwnych widziadel" ${ }^{33}$. Wspomniany wyżej poemat prozą Pragnę malować - w zasadzie Pragnienie malowania (Le désir de peindre) dotyczy poezji. Malowanie czarnego słońca jest tożsame $\mathrm{z}$ umieraniem pod spojrzeniem piękności. Niespełniona chęć obu tych aktywności ma charakter sublimacyjny i jest gwarantem kreacji.

W Lubię wspomnienie... (J'aime le souvenir...) nowoczesne, ułomne piękno jest odkrywane dzięki spowijającej świat czerni - to, co widzi poeta, to czarny obraz („noir tableaux”), który przeraża, ale właśnie dzięki temu pozwala wydobyć „piękności nowe” („beautés inconnues”; KZ, B. Wydżga, s. 22, 23). Metafora płótna malarskiego powraca również w Grze (Le Jeu), gdzie czarny obraz - „noir tableau” - nie jest przez podmiot malowany,

${ }^{41}$ Ch. Baudelaire, Zmierzch [w:] idem, Sztuczne raje, s. 208. Na temat gnostyckiego doświadczenia świata w Kwiatach zła, w którym ciemność jest światłem, zob. P. Labarthe, op.cit., s. 118. Zob. też: A. Guyaux, Le XIXe siècle à l'ombre des Lumières, „Revue italienne d'études françaises. Littérature, langue, culture" 2013, no 3, s. 3.

${ }^{42}$ Ch. Baudelaire, Ryszard Wagner $i$ "Tannhäuser "w Paryżu, przeł. E. Burska, S. Cichowicz [w:] idem, Sztuka romantyczna, s. 370 [podkr. M.S.].

${ }^{43}$ Idem, Sztuczne raje. Opium i haszysz [w:] idem, Sztuczne raje, s. 126. 
a widziany w nocnym marzeniu: „Oto obraz żałobny, co w noc jedną ciemną / Swoje smutne kontury roztoczył przede mną” („Voilà le noir tableau qu'en un rêve nocturne / Je vis se dérouler sous mon œil clairvoyant"; KZ, W. Gomulicki, s. 254, 255). Podmiot przyjmuje pozycję voyeura, podglądacza zazdroszczącego graczom pasji. Obraz jest czarny, oko marzyciela - jasnowidzące („œil clairvoyant”), jednak, co ważne, dostrzega on także samego siebie wśród graczy. Ten gest podwojenia, mise en abyme, staje się gestem ironicznym i melancholijnym zarazem. „Ja” - jak w wielu innych „kwiatach zła" - spogląda na siebie jak na innego, dystansuje się i wobec graczy, którym zazdrości, i wobec siebie oraz własnej zawiści. W tym sensie czarny obraz jest też autoportretem, a wydobywanie go i rozjaśnianie, opisywanie, ujmowanie w słowa to gest nie tylko translatorski (przełożenia jednego medium na inne), lecz także stricte poetycki.

Porównanie poety do malarza powraca również w innych „kwiatach zła”, na przykład w Widmie (Un Fantôme). Co istotne, także w tym utworze bohater jest skazany (pobrzmiewa znów ironiczne błogosławieństwo-przekleństwo poety z początku cyklu) na malowanie na płótnie ciemności: „Jestem jak potępieniec, przez Boga szydercę / Skazany na tle cienia malować - niestety!” (,Je suis comme un peintre qu'un Dieu moqueur / Condamne à peindre, hélas ! sur les ténèbres"; KZ, A. M-ski, s. 100, 101). Można chyba dodać, że jeśli obraz miałby być malowany czarną farbą lub czarnym atramentem na czarnym tle, byłby zaprzeczeniem reprezentacji, stawałby się niezrozumiały. Ponownie Baudelaire zbliża się do fantazmatu poezji poza granicami ekspresji i zrozumienia. Cóż jednak ostatecznie zostaje z portretu umarłej? „Szkic, kartka niknąca” (,Rien qu'un dessin fort pâle, aux trois crayons”; KZ, A. M-ski, s. 104, 105), blady rysunek. Zwycięża czerń, ale czerń Czasu nazwanego czarnym zabójcą Życia i Sztuki („Morderco czarny, życiu, sztuce wrogi” / „Noir assassin de la Vie et de l'Art"; KZ, A. M-ski, s. 104, 105), przypominającego Czarnego Doktora Alfreda de Vigny'ego - romantyka, który wprowadził do literatury postać poète maudit.

Walka z czasem jest walką o pamięć i prowadzi do porażki artysty. A jednak poeta swej porażce usilnie - rozpaczliwie i heroicznie - przeczy i niejako wbrew niej znaczy na płótnie trzema ołówkami, niewyraźnym pismem kolejne wersy. Dlatego ten blady szkic jest tak cenny mimo swej nikłości. Czas wymazuje obraz, bo wymazuje pamięć, która jest obok wyobraźni jednym z warunków tworzenia; beznadziejne zmaganie z czasem to próba zachowania jej szczątków. Pamięć staje się dla melancholika przytłaczająca, jest on bowiem zwrócony zawsze w kierunku przeszłości - w Spleenie II tysiącletnia pamięć jest tak ciężka, że petryfikująca. Sartre nazywa tę postawę Baudelaire'a 
„radykalnym passeizmem” ${ }^{44}$. W Opętaniu poeta odsuwa od siebie pamięć minionych postaci, a one wracają niechciane; w Wyznaniu (Confession) niewyblakłe wspomnienie trwa na mrocznym tle duszy („W głębi duszy posępnej nie blaknie wspomnienie / Tej jasnej, miłej mi godziny”; „sur le fond ténébreux de mon âme / Ce souvenir n'est point pâli”; KZ, J. Waczków, s. 118, 119) i zostaje opisane w wierszu, przetworzone w tekst; w Harmonii wieczornej przeszłość jest świetlista, pozostawia ślady zbierane przez podmiot, który ujawnia się dopiero na końcu wiersza, wyznając: „Twoje wspomnienie płonie we mnie jak gromnica” („,Ton souvenir en moi luit comme un ostensoir!”; KZ, M. Leśniewska, s. 124, 125; w porównaniu Baudelaire'a chodzi o monstrancję, nie o gromnicę). Wszystkie wymienione utwory mówią o wspomnieniu w kategoriach jasności, lśnienia, blasku, nawet jeśli to blask blady, wyróżniającego się na tle mroku konstytutywnego dla podmiotu. Dopiero połączenie blasku i czerni - w tym przypadku w pracy pamięci - daje impuls twórczy.

Podróż (Le Voyage) zajmuje w Kwiatach zła szczególne miejsce - jako utwór zamykający cykl. Oto pierwsza z dwóch strof ostatniej, VIII części utworu:

O Śmierci, stary szyprze, odbijaj - dal woła!

Ten kraj nas nudzi. W droge, do nowej przestrzeni!

Chociaż niebo i morze sa czarne jak smoła,

Nasze serca - ty znasz je - sa pełne promieni!

Ô Mort, vieux capitaine, il est temps ! levons l'ancre.

Ce pays nous ennuie, ô Mort! Appareillons !

Si le ciel et la mer sont noirs comme de l'encre,

Nos cœurs que tu connais sont remplis de rayons !

(KZ, M. Leśniewska, s. 344, 345)

Chcę zwrócić uwagę na dwa końcowe wersy tej strofy, przywołujące śmierć i atrament melancholii ${ }^{45}$. Czerń nieba i morza jest porównana do czerni atramentu (nie smoły, tak jak w przekładzie) - raz jeszcze Baudelaire dokonuje odwrócenia porządku natury i kultury. W rozpoczęciu zdania od „si” - ,jeśli”nie widzę przeciwstawienia (jak w tłumaczeniu: „chociaż”), ale warunkowe, logiczne następstwo: „Jeśli niebo i morze są czarne jak atrament, / Nasze serca, które znasz, są pełne promieni”. Serca są promienne właśnie dlatego - a nie pomimo tego - że niebo i morze są czarne. Remedium na nudę i melancholię znaleźć się ma, tautologicznie, w nich samych, w blasku bijącym z mroku,

${ }^{44}$ J.-P. Sartre, op.cit., s. 112-113. Zob. też: s. 114-119 (o melancholicznym pragnieniu świadomości przeszłości, utożsamieniu przeszłości i wieczności, wymogu bycia gdzie indziej). Starobinski pisze o „efekcie eternizacji”, zob. idem, Atrament..., s. 321-334.

${ }^{45}$ Nawiązuję tu oczywiście do tytułu rozprawy J. Starobinskiego. 
w świetlistej czerni. W związku z tym można się zgodzić z Patrickiem Labarthem, że czarny atrament nieba i morza $\mathrm{w}$ wierszu to ten sam atrament, którym pisze się poemat ${ }^{46}$.

$$
* * *
$$

Baudelaire - uznany przez Pierre'a Bourdieu za pioniera i herosa sztuki nowoczesnej - wyzyskuje melancholię, by stworzyć sztukę opartą na łamaniu zasad, sytuującą się w opozycji wobec pola władzy, którego celem jest narzucanie norm ${ }^{47}$. Ten wymiar buntu ma niewątpliwie także stworzona przez poetę - w jego pismach estetycznych powiązana $\mathrm{z}$ melancholią - koncepcja dandyzmu. Melancholia - z zasady pozanormatywna - stała się dla tego pisarza podstawą do sformułowania własnej definicji piękna, piękna wykraczającego poza normę, bo ułomnego. Co jednak najistotniejsze, melancholijna poezja Baudelaire'a to poezja o poezji, poezja paradoksalna w tym sensie, że przecząca bezruchowi, acedii, twórczej stagnacji, choć zachowująca swój wymiar negatywny. To twórczość, która sięga do krańcowych obszarów artykulacji, sprawdza własne możliwości, powstaje niejako przeciwko samej sobie. Wraz z ekspansją czerni Kwiaty zła docierają do granic języka - ciemność mowy, niezrozumiałość pociągająca poetę, przeciwstawiona jest jasności (także tekstu wyartykułowanego), ale tylko po to, by to przeciwstawienie zamazać. Wiersze odsłaniają wyczerpanie języka i wykuwanie nowego na ruinach starego (kolejnym etapem tego wykuwania będą zrywające z mową wiązaną poematy prozą z Paryskiego spleenu). W tym poetologicznym sensie - bardziej niż we wskazywanym przez Bourdieu socjologicznym - jest to poezja rewolucyjna. Jej nowość oddaje metafora świetlistej czerni, blasku pozbawionego źródła, lumen obscurum, światła wyrastającego ze swego zaprzeczenia, poezji powstającej z utraty i mroku.

\section{Bibliografia}

Acquisto J., The Fall out of Redemption. Writing and Thinking beyond Salvation in Baudelaire, Cioran, Fondane, Agamben, and Nancy, New York-London: Bloomsbury 2015.

${ }^{46}$ Zob. P. Labarthe, op.cit., s. 158. J.-M. Maulpoix doda, że poemat musi być dla Baudelaire'a odtąd przedmiotem melancholijnym - między wiecznym a przejściowym, pożądaniem piękna i świadomością brzydoty, mówiącym przez alegorię; zob. idem, op.cit., s. 32 .

${ }^{47}$ Zob. P. Bourdieu, Reguty sztuki. Geneza i struktura pola literackiego, przeł. A. Zawadzki, Kraków: Universitas 2001, zwł. cz. 1: Trzy stadia pola. 
Antoine G., La Nuit chez Baudelaire, „Revue d'Histoire littéraire de la France” 1967, no 2.

Bator J., Julia Kristeva - kobieta $i$ „,symboliczna rewolucja”, „Teksty Drugie” 2000, nr 6.

Baudelaire Ch., Kwiaty zła, wybór M. Leśniewska, J. Brzozowski, posłowie J. Brzozowski, Kraków: Wydawnictwo Literackie 1994.

Baudelaire Ch., La Belle Dorothée [w:] idem, Euvres complètes, texte établi, présenté et annoté par C. Pichois, t. I, Paris: Gallimard 1975.

Baudelaire Ch., Malarz życia nowoczesnego 1846 [w:] idem, Rozmaitości estetyczne, wstęp i przekł. J. Guze, przyp. i koment. C. Pichois, przeł. J.M. Kłoczowski, Gdańsk: słowo/obraz terytoria 2000.

Baudelaire Ch., Salon 1846 [w:] idem, Rozmaitości estetyczne, wstęp i przekł. J. Guze, przyp. i koment. C. Pichois, przeł. J.M. Kłoczowski, Gdańsk: słowo/obraz terytoria 2000.

Baudelaire Ch., Sztuczne raje, wstęp i przekł. R. Engelking, przyp. i koment. C. Pichois, Gdańsk: słowo/obraz terytoria 2009.

Baudelaire Ch., Sztuka romantyczna, red. R. Engelking, wstęp A. Kijowski, koment. i przyp. C. Pichois, przeł. A. Kijowski, T. Swoboda, E. Burska, S. Cichowicz, M. Sawiczewska, Gdańsk: słowo/obraz terytoria 2003.

Benjamin W., Paryz-stolica dziewiętnastego wieku [w:] idem, Twórca jako wytwórca. Eseje i rozprawy, przeł. R. Reszke, Warszawa: KR 2011.

Bieńczyk M., Melancholia. O tych, co nigdy nie odnajda straty, Warszawa: Sic! 1998.

Bieńczyk M., Oczy Dürera. O melancholii romantycznej, Warszawa: Sic! 2002.

Bourdieu P., Reguty sztuki. Geneza i struktura pola literackiego, przeł. A. Zawadzki, Kraków: Universitas 2001.

Carter A., Czarna Wenus [w:] eadem, Czarna Wenus. Opowiadania, wybór, przekł., wstęp i przyp. A. Ambros, Warszawa: Czytelnik 2000.

Compagnon A., Baudelaire moderne et antimoderne [film z nagraniem wykładu], https://www.college-de-france.fr/site/antoine-compagnon/course-2012-01-1016h30.htm [dostęp: 15.12.2020].

Compagnon A., Les antimodernes de Joseph de Maistre à Roland Barthes, Paris: Gallimard 2005.

Dandrey P., Anthologie de l'humeur noire. Écrits sur la mélancolie d'Hippocrate à l'" Encyclopédie », Paris: Gallimard 2005.

Dufour P., "Les Fleurs du Mal »: dictionnaire de mélancolie, „Littérature” 1988, no 4: Matière de poésie.

Foucault M., Czym jest Oświecenie? [w:] idem, Filozofia, historia, polityka. Wybór pism, przekł. i wstęp D. Leszczyński, L. Rasiński, Warszawa-Wrocław: PWN 2000.

Freud S., Żałoba $i$ melancholia [w:] idem, Psychologia nieświadomości, przeł. R. Reszke, Warszawa: KR 2007.

Froidevaux G., Baudelaire. Représentation et modernité, Paris: José Corti 1989.

Guyaux A., Le XIXe siècle à l'ombre des Lumières, „Revue italienne d'études françaises. Littérature, langue, culture" 2013, no 3.

Hirt A., Baudelaire. Exposition de la poésie, Paris: Kimé 1998.

Hugo V., Ce que dit la bouche d'ombre [w:] idem, Oeuvres poétiques complètes, éd. F. Bouvet, Paris: J.J. Pauvert 1961. 
Hugo V., Usta ciemności [w:] idem, Liryki i poematy, przeł. Z. Bieńkowski, Warszawa: Państwowy Instytut Wydawniczy 1962.

Juden B., Traditions orphiques et tendances mystiques dans le romantisme français (1800-1855), Paris: Éditions Klincksieck 1971.

Klibansky R., Panofsky E., Saxl F., Saturn i melancholia. Studia z historii, filozofii, przyrody, medycyny, religii oraz sztuki, przeł. A. Kryczyńska, Kraków: Universitas 2009.

Kristeva J., Czarne stońce. Depresja i melancholia, przeł. M.P. Markowski, R. Ryziński, wstęp M.P. Markowski, Kraków: Universitas 2007.

Labarthe P., Spleen et création poétique dans «Les Fleurs du Mal » [w:] Poètes du spleen: Leopardi, Baudelaire, Pessoa, éd. P. Daros, Paris: Honoré Champion 1997.

Markiewicz Z., Teologia ubioru? O poszukiwaniu sacrum w powierzchowności stroju. Baudelaire'owska koncepcja mody XIX wieku a widzenie szat (liturgicznych) przez Nowosielskiego, „Humanistyka i Przyrodoznawstwo” 2011, nr 17.

Maulpoix J.-M., Le spleen baudelairien: une melancholie moderne [w:] Poétiques du néant. Leopardi, Baudelaire, Pessoa, éds. B. Didier, D. Levy-Bertherat, G. Ponnau, Paris: CDU-Sedes 1998.

Oehler D., Le Spleen contre l'oubli, juin 1848: Baudelaire, Flaubert, Heine, Herzen, Paris: Payot e Rivages 1996.

Quesnel M, Baudelaire solaire et clandestin, Paris: Presses Universitaires de France 1987.

Reid M., Misogynie de Baudelaire [w:] Masculin / féminin. Le XIX siècle à l'épreuve du genre, éd. Ch. Bertrand-Jennings, Toronto: Centre d'Études du XIX ${ }^{\mathrm{e}}$ siècle Joseph Sablé 1999.

Richter M., Baudelaire, "Les Fleurs du mal ». Lecture intégrale, Genève: Slatkine 2001.

Sartre J.-P., Baudelaire, przeł. K Jarosz, przedm. M. Leiris, posłowie P. Małochleb, Kraków: Zielona Sowa 2007.

Schneider L., Symptômes de ruines " fragments d'avenir ", „L'Année Baudelaire” 1998, vol. 4: Postérités de Baudelaire.

Siwiec M., , Czarna przędza” Baudelaire'a, „Poznańskie Studia Polonistyczne. Seria Literacka" 2020, nr 37.

Siwiec M., Norwid, Baudelaire i reguty sztuki, „Teksty Drugie” 2020, nr 5.

Skagen M.V., Ennui vs mélancolie [w:] "Les Fleurs du mal ». Acte du colloque de la Sorbonne de 10 et 11 janvier 2003, éds. A. Guyaux, B. Marchal, Paris: Presses de l'Université de Paris-Sorbonne 2003.

Sosień B., Francuski romantyk na wyspach greckich [w:] Dziedzictwo Odyseusza. Podróż, obcość $i$ tożsamość, identyfikacja, przestrzeń, red. M. Korytowska, O. Płaszczewska, Kraków: Universitas 2007.

Starobinski J., Atrament melancholii, przeł. K. Belaid, Gdańsk: słowo/obraz terytoria 2017.

Starobinski J., La Mélancolie au miroir. Trois lectures de Baudelaire, Paris: Julliard 1989.

Śniedziewski P., Czarne słońca romantyków, Warszawa: Sic! 2018.

Śniedziewski P., Spleen - dialog anatomii z psychologia. Problemy recepcji i przekładu, „Rocznik Komparatystyczny” 2010, nr 1. 
Śniedziewski P., Spoglądać w zmacone zwierciadło (Baudelaire) [w:] idem, Melancholijne spojrzenie, Kraków: Universitas 2011.

Wilhelm F., Baudelaire. L'écriture du narcisme, Paris: L'Harmattan 1997. 